\title{
Adipose cell size and glucose tolerance in obese children and effects of diet
}

\author{
C. G. D. BROOK and JUNE K. LLOYD \\ From the Institute of Child Health, 30 Guilford Street, London
}

\begin{abstract}
Brook, C. G. D., and Lloyd, J. K. (1973). Archives of Disease in Childhood, 48, 301. Adipose cell size and glucose tolerance in obese children and effects of diet. Adipose cell size and the glucose and insulin response to an oral glucose load have been studied in 26 obese children. Adipose cells were found to be enlarged, and hyperinsulinaemia was demonstrated both in the fasting state and also after oral glucose. The degree of hyperinsulinaemia could not be predicted by adipose cell size.

In 14 children studies were repeated after a period of weight loss. A marked fall in fasting serum insulin occurred in all children over the first week of treatment. A reduction in adipose cell size was demonstrated over a longer period, but there was no change in the total number of adipose cells. In 7 children who were still losing weight when a second glucose tolerance test was performed, insulin levels after oral glucose were reduced, but there was no reduction in insulin levels in 7 children studied after they had stopped losing weight. The reduction in body fat and adipose cell size in these two groups of children was no different. Thus it was not possible to predict the fall in insulin levels from changes in body composition or adipose cell size.

These data do not support the hypothesis of a direct causal relation between the increase in adipose cell size and the hyperinsulinaemia of obesity.
\end{abstract}

Hyperinsulinism with normal blood glucose values has been reported both in obese adults (Kreisberg et al., 1967) and in obese children (Chiumello et al., 1969), and this implies peripheral insensitivity to the action of insulin. Salans, Knittle, and Hirsch (1968) found that large adipose cells in vitro were less sensitive than small cells to the action of insulin in basal glucose uptake, and that when the adipose cell size of obese subjects had been reduced by diet, the sensitivity of their cells to insulin was increased. Plasma insulin levels were raised in the obese subjects and fell when adipose cell size was reduced. It was therefore suggested that adipose cell size may be the main cause of the hyperinsulinism of obesity. Direct correlations of adipose cell size with plasma insulin levels have shown a statistically significant correlation $(P<0 \cdot 05)$, but the correlation coefficient was only 0.41 (Björntorp and Sjöström, 1971). The present paper reports studies on adipose cell size and plasma insulin in obese children, together with the effects of diet on these measurements.

Received 3 August 1972.

\section{Methods}

Studies were carried out on 26 obese children (10 boys, 16 girls), aged 1.4 to 16.6 years. All were at least $20 \%$ above the weight expected for their height and had triceps and/or subscapular skinfold thicknesses over the 90th centiles (Tanner and Whitehouse, 1962). None of the patients was suffering from any defined endocrine disorder.

Follow-up studies were done on 18 of the children, all of whom were treated in hospital with a $350 \mathrm{kcal}$ diet containing $29 \mathrm{~g}$ protein, $28 \mathrm{~g}$ carbohydrate, and $13.5 \mathrm{~g}$ fat daily. All subjects were weighed to the nearest $0.1 \mathrm{~kg}$ in underclothes on beam scales and their height was measured using a stadiometer. Total body fat was calculated from measurements of skinfold thickness (Brook, 1971a).

Adipose tissue was obtained by needle aspiration from subcutaneous tissue over the buttock, and the adipose cell lipid content (a measure of adipose cell size) was estimated by a minor modification (Brook, 1971b) of the method of Hirsch and Gallian (1968). The total number of adipose cells in the body was calculated from the mean weight of lipid per cell and the total body fat.

Oral glucose tolerance tests were performed within the first 48 hours of hospital admission after a 12-hour 
overnight fast. It was not possible to determine accurately the calorie content and composition of diets of the children before admission to hospital. In children under 5 years of age capillary blood was collected by finger prick; in older children venous blood was collected from an indwelling needle. Samples were taken fasting and at 30,60,90, 120, and 150 minutes after a glucose load of $1.75 \mathrm{~g} / \mathrm{kg}$ up to a maximum of $50 \mathrm{~g}$.

Glucose was estimated using a glucose oxidase method adapted for the autoanalyser (Trinder, 1969). Control values were obtained from 23 children of comparable ages being investigated for malabsorption but who were eventually shown to be normal.

Serum insulin levels were measured using a modification (Grant, 1968) of the double antibody radioimmunoassay technique (Morgan and Lazarow, 1963). Control values for insulin in children were those obtained by Grant (1967) using the same methods and laboratories.

In the children treated in hospital with a $350 \mathrm{kcal}$ diet, fasting blood samples were collected for estimation of glucose and insulin before and 1 week after starting treatment in all 18 children, 4 weeks after starting treatment in 15, and 8 weeks after in 10 .

In 14 children oral glucose tolerance tests and adipose tissue sampling were repeated after weight loss (see Table). These tests were performed on 7 children who were still on a low calorie diet and losing weight (Group A), and they were performed on 7 others who had stopped losing weight and the calorie intake had been increased to $800 \mathrm{kcal}, 50 \mathrm{~g}$ protein, $50 \mathrm{~g}$ carbohydrate, and $30 \mathrm{~g}$ fat to maintain the new weight (Group B). In 1 patient two tests were performed, one in each of these situations.

\section{Results \\ Initial investigations.}

Glucose tolerance. The only difference in glucose tolerance between the obese and control children was that in obese children the blood glucose at 150 minutes was still significantly greater than the fasting values (Fig. 1).

Insulin levels. Hyperinsulinaemia was present in the obese children (Fig. 1) both in the fasting
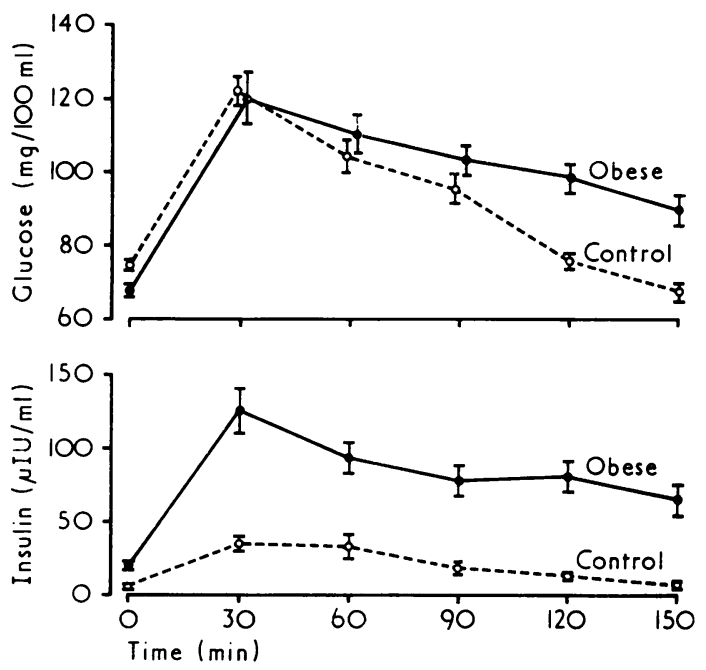

FIG. 1.-Mean ( $\pm S E M)$ blood glucose and immunoreactive insulin curves after oral glucose in 26 obese children.

state and after the glucose load. There was a significant correlation $(r=0.43 \mathrm{P}<0.05)$ between the area under the insulin curve in obese subjects and the total body fat (expressed as a percentage of body weight), but there was no correlation between the insulin response on the one hand and the length of history of obesity or the age of the child on the other. Though the controls were not matched for age with the obese children, the magnitude of the difference in insulin response between the obese and control groups was far greater than any difference that could have been accounted for by the increase in insulin values which occur with age (Grant, 1968).

Adipose cell size. The mean weight of lipid in the adipose cells of the obese children $(0.72 \mu \mathrm{g}$, SD 0.22$)$ was significantly greater $(P<0.001)$ than that in the cells of control children of normal

TABLE

Effect of weight loss on oral glucose tolerance in two groups of children

\begin{tabular}{|c|c|c|c|c|c|c|}
\hline & \multicolumn{2}{|c|}{ Change in body fat $\%$ of weight } & \multicolumn{2}{|c|}{ Change in adipose cell size ( $\mu$ g lipid) } & \multicolumn{2}{|c|}{ Change in area under insulin curve } \\
\hline & Mean & SD & Mean & SD & Mean & SD \\
\hline $\begin{array}{l}\text { Group A } \\
\text { Group B }\end{array}$ & $\begin{array}{l}-11 \cdot 6 \\
-9.6\end{array}$ & $\begin{array}{l}3 \cdot 83 \\
4 \cdot 37\end{array}$ & $\begin{array}{l}-0.37 \\
-0.26\end{array}$ & $\begin{array}{l}0 \cdot 21 \\
0 \cdot 12\end{array}$ & $\begin{array}{r}-388 \cdot 9 \\
-16 \cdot 0\end{array}$ & $\begin{array}{l}194 \cdot 7 \\
186 \cdot 0\end{array}$ \\
\hline $\begin{array}{l}\text { ' } t \text { ' value } \\
\mathbf{P} \text { value }\end{array}$ & \multicolumn{2}{|c|}{$\begin{array}{r}0.90 \\
\text { NS }\end{array}$} & \multicolumn{2}{|c|}{$\begin{array}{c}1 \cdot 20 \\
\text { NS }\end{array}$} & \multicolumn{2}{|c|}{$\begin{array}{r}3.66 \\
<0.01\end{array}$} \\
\hline
\end{tabular}

NS, not significant. 
weight $(0.30 \mu \mathrm{g}$, SD 0.14) (Brook, 1972). Fig. 2 shows the relation between the area under the insulin curve and the size of the adipose cells. Though there is a significant correlation between the two $(r=0.42 \mathrm{P}<0.05)$, it is not high enough to make possible any useful prediction of insulin response from adipose cell size.

Effect of weight loss. All children treated with $350 \mathrm{kcal}$ diet lost weight. The weight loss was maximal in the first week of treatment when the mean weight loss was $5.5 \%$ of the baseline weight (SD 1.68). Thereafter, weight loss was remarkably constant at about $2 \%$ of the previous week's weight per week. Neither the adipose cell size nor the duration or degree of obesity nor the age of the child had any effect on the rate of weight loss. The amount of body fat (expressed as a percentage of the body weight) lost during the whole period of dieting was similar in the two groups (A and B) of children (see Table).

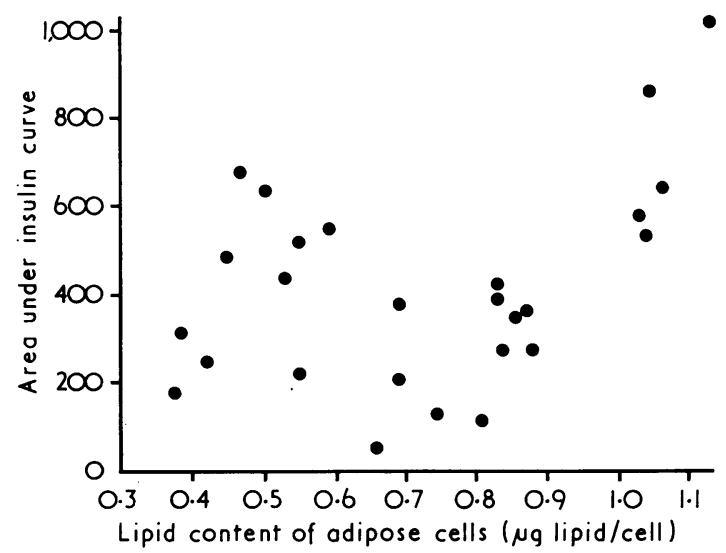

Fig. 2.-Relation of adipose cell size to area under the insulin curve. $r=0.42$.

Glucose and insulin levels. During weight loss there was a marked fall in fasting values of glucose and insulin during the first week of treatment, but no subsequent changes (Fig. 3). Oral glucose tolerance tests performed at the end of hospital admission showed the lag type of glucose curve typical of starvation in Group A (patients still on diet and losing weight). In the children of Group B (patients maintaining weight) the glucose tolerance was normal, and in these patients the abnormality that was noted in the first test, when the 150-minute glucose level was raised over the fasting value, was abolished. In Group A patients there was a fall in the area under the insulin curve

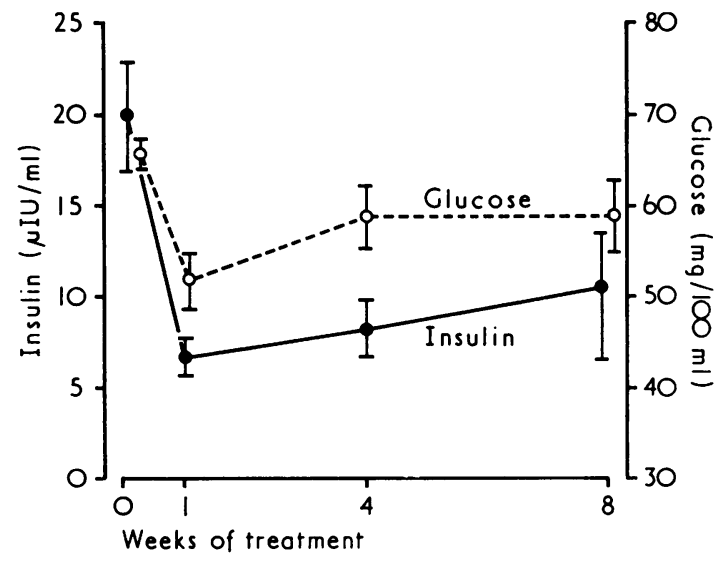

FIG. 3.-Mean ( $\pm S E M)$ fasting blood glucose and immunoreactive insulin levels during treatment with $350 \mathrm{kcal}$ diet. Number of patients: 18 before and 1 week after starting treatment, 15 at 4 weeks, and 10 at 8 weeks.

( $P<0.001$ ), but in the children of Group B there was no reduction (see Table). In the 1 child who had two tests done after weight loss there was reduction in the area under the insulin curve in the test done while she was losing weight, but no change from baseline when her diet was increased and weight loss ceased.

Adipose cell size. After weight loss there was a reduction in adipose cell size $(-0.31 \mu \mathrm{g}$ lipid/cell, SD $0 \cdot 17, P<0 \cdot 01$ ), but no change in the total number of adipose cells (Fig. 4). There was no significant difference between the reduction in the size of the adipose cells in the two groups of children (see Table).

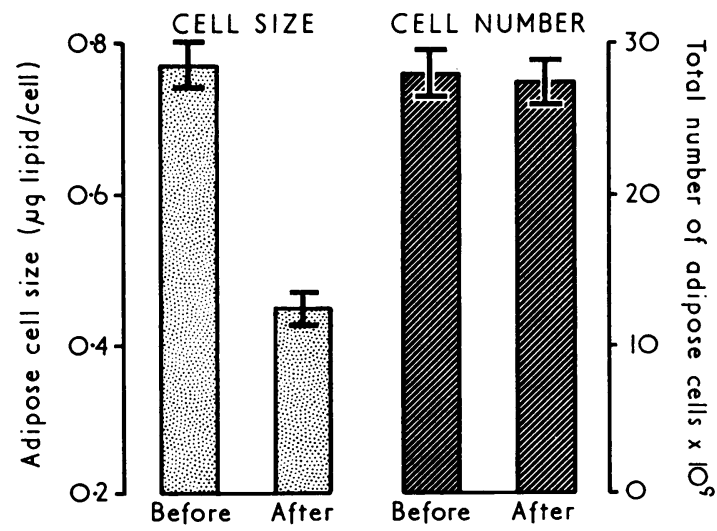

FIG. 4.-Mean ( $\pm S E M)$ values of adipose cell size, and number before and after weight loss in 14 obese children. 


\section{Discussion}

The work of Davidson (1972) indicates that the adipose tissue of obese subjects may not be insensitive to insulin, and suggests that insensitivity of the muscle mass and/or a circulating insulin antagonist could be more important in the insulin resistance of obesity. The present results likewise do not support the concept that adipose cell size is the most important cause of the hyperinsulinism of obesity. The rapid fall in fasting insulin values in the first week of treatment suggests that hyperinsulinism is more allied to the dietary intake; neither body fat mass nor adipose cell size change this rapidly. The finding of hyperinsulinaemia in the fasting state in these children adds evidence to the suggestion (Perley and Kipnis, 1966) that peripheral tissues of obese subjects are basically 'insulinized' and that a greater than normal rise in insulin is required to produce the increment in glucose uptake which must follow a glucose load if homeostasis is to be maintained. This is in keeping with recent evidence which suggests that the carbohydrate content of the diet is important in the hyperinsulinism of obesity, because increased levels of insulin are found in patients who were losing weight on high carbohydrate diets (Grey and Kipnis, 1971).

Prolonged glucose infusion and consequent insulin release alone induces a state of insulin resistance (Kreisberg et al., 1967) and excessive food intake is likely, therefore, to do so as well. A new steady state may thus be reached in which the adipose cells are larger, there is hyperinsulinism, and the insulin required in response to a glucose load is greater. The present data show that during weight loss all these events are reversed, and favour the hypothesis that both the rise in adipose tissue mass and adipose cell size on the one hand and the hyperinsulinism on the other result from an increased intake of carbohydrate.
They do not show any direct causal relation between adipose cell size and hyperinsulinaemia.

C.G.D.B. gratefully acknowledges the financial support of the Wellcome Trust.

\section{REFERENCES}

Björntorp, P., and Sjöström, L. (1971). Number and size of adipose tissue fat cells in relation to metabolism in human obesity. Metabolism, 20, 703.

Brook, C. G. D. (1971a). Determination of body composition of children from skinfold measurements. Archives of Disease in Childhood, 46, 182.

Brook, C. G. D. (1971b). Composition of human adipose tissue from deep and subcutaneous sites. British fournal of Nutrition, 25, 377 .

Brook, C. G. D. (1972). Obesity in childhood. M.D. Thesis. University of Cambridge.

Chiumello, G., Guercio, M. J. Del, Carnelutti, M., and Bidone, G. (1969). Relationship between obesity, chemical diabetes and Beta pancreatic function in children. Diabetes, 18, 238.

Davidson, M. B. (1972). Effect of obesity on insulin sensitivity of human adipose tissue. Diabetes, $\mathbf{2 1}, 6$.

Grant, D. B. (1967). Fasting serum insulin levels in childhood. Archives of Disease in Childhood, 42, 375.

Grant, D. B. (1968). Serum-insulin levels in children during glucose tolerance tests. Acta Paediatrica Scandinavica, 57, 297.

Grey, N., and Kipnis, D. M. (1971). Effect of diet composition on the hyperinsulinemia of obesity. New England fournal of Medicine, 285, 827.

Hirsch, J., and Gallian, E. (1968). Methods for the determination of adipose cell size in man and animals. Fournal of Lipid Research, 9, 110.

Kreisberg, R. A., Boshell, B. R., DiPlacido, J., and Roddam, R. F. (1967). Insulin secretion in obesity. New England fournal of Medicine, 276, 314

Morgan, C. R., and Lazarow, A. (1963). Immunoassay of insulin: two antibody system. Diabetes, 12, 115 .

Perley, M., and Kipnis, D. M. (1966). Effect of glucocorticoids on plasma insulin. New England fournal of Medicine, 274, 1237.

Salans, L. B., Knittle, J. L., and Hirsch, J. (1968). Role of adipose cell size and adipose tissue insulin sensitivity in the carbohydrate intolerance of human obesity. Fournal of Clinical Investigation, 47, 153.

Tanner, J. M., and Whitehouse, R. H. (1962). Standards for subcutaneous fat in British children. British Medical fournal, 1, 446.

Trinder, P. (1969). Determination of blood glucose using an oxidase-peroxidase system with a non-carcinogenic chromogen. Fournal of Clinical Pathology, 22, 158.

Correspondence to Dr. C. G. D. Brook, Kinderspital, Steinwiesstrasse 75, 8032 Zürich, Switzerland. 